\title{
Bovine Babesiosis in Calves - Review of Three Cases
}

\author{
Sivajothi $\mathbf{S}^{1}$, Sudhakara Reddy B ${ }^{2 *}$ \\ 1Department of Veterinary Parasitology, India \\ 2Department of Veterinary Clinical Complex, India
}

*Corresponding author: Sudhakara Reddy B, Department of Veterinary Clinical Complex, Faculty of Veterinary Medicine, Andhra Pradesh, India Submission: 眥January 12, 2018; Published: 眥 May 29, 2018

\begin{abstract}
Based on the history, clinical and laboratory examination of the blood smears, diagnosis of the bovine babesiosis was done in three calves. Calves showed fever, decreased milk and feed intake, tachypnea, tachycardia, haemoglobinuria and anemia. They were successfully treated with diminazene aceturate along with supportive therapy.
\end{abstract}

Keywords: Calves; Bovines; Babesiosis; Diminazene

\section{Introduction}

Haemoprotozoan diseases are economically important diseases in large animal practice. Among the different haemoprotozoan diseases, Babesiosis is one of the vector-borne and important diseases in livestock. Babesiosis is caused by intra erythrocytic protozoan parasites of the genus Babesia that infect a wide range of domestic and wild animals [1]. Babesia shows reverse age immunity in cattle due to B. bigemina [2]. Present paper puts the report on babesiosis in three calves under six month age old.

\section{Materials and Methods}

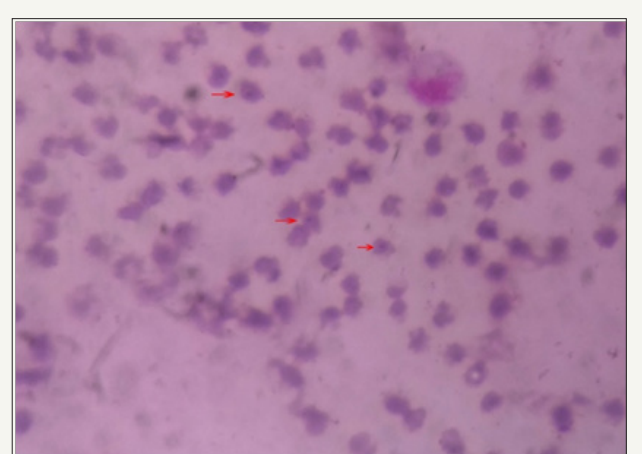

Figure 1: Presence of Intra-erythrocytic Babesia spp. organisms (1000X).

Three calves less than six month age were diagnosed suffering from clinical babesiosis at College of Veterinary Science, Proddatur. Clinical examination revealed dullness, pale mucus membranes, elevated rectal temperature, tachycardia, tachypnoea and passing of red colour urine in two calves. Microscopic examination of the stained peripheral blood smear examination revealed piroplasms of Babesia bigemina with morphology varying from ovoid or vacuolar forms to annular ring forms typically paired pyriform (Figure 1). Hematology revealed reduced haemoglobin (6.4 to $7.2 \mathrm{~g} / \mathrm{dL}$ ) and packed cell volume (19\% to $23 \%$ ). Urine analysis revealed the presence of protein, ketone bodies, glucose and blood.

\section{Treatment and Discussion}

Based on clinical signs and laboratory examination the condition was diagnosed to be bovine babesiosis. Calves were treated with inj. diminazene aceturate (@ 5mg/kg body, IM),inj. meloxicam (@ $0.5 \mathrm{mg} / \mathrm{kg}$ body weight IM) on the day of presentation. Parentral administration of four doses of iron dextran (@2ml/ animal) at weekly twice and daily oral liver tonics was advised. After completion of two weeks of therapy, animals responded well and attain its normal activities.

Clinical babesiosis is characterized by elevated body temperature, intravascular hemolysis which is manifested by the complex of anemia, hemoglobinuria and jaundice. Development of the signs varies depending on the species of parasite and the host age and immune status. Babesiosis commonly noticed in the in adult cattle but, during the outbreak of the disease in endemic areas, calves also infected and they may develop a long-term immunity [3]. Inverse age resistance of the babesiosis was recorded (adult animals are more susceptibility than calves). This might be due to rapid immune responses to primary infection by the calves through a complex immune mechanism [4]. 
Observed clinical signs and hematological changes were in consonance with the previous reports in different species of animals $[1,5]$. Previously, babesiosis was reported in young calves [5,6]. It was reported that intra-uterine transmission can also possible in calves [7]. It was reported that calves in enzootic areas become infected by the 11 weeks and it was a supportive document to the present study [8]. Development of the abnormal findings in dogs also reported in babesiosis [9]. Recorded haematological findings and response to the diminazene supported by the previous reports in other species of animals $[1,10]$.

\section{Conclusion}

Present study put report on the occurrence of clinical babesiosis in calves and it successful management.

\section{Acknowledgement}

Authors are thankful to the authorities of the Sri Venkateswara Veterinary University for providing facilities to carry out this work.

\section{References}

1. Sudhakara Reddy B, Sivajothi S, Varaprasad Reddy LS, Solmon Raju KG (2016) Clinical and laboratory findings of Babesia infection in dog. J Parasit Dis 40(2): 268 - 272.

2. Soulsby EJL (2005) Helminths, Arthropods and Protozoa of Domesticated Animals. $\left(7^{\text {th }}\right.$ edn), Bailliere Tindal, London, UK.
3. Gohil S, Herrmann S, Günther S, Cooke BM (2013) Bovine babesiosis in the 21st century: Advances in biology and functional genomics. Int J Parasitol 43(2):125-132.

4. Zintl A, Gray JS, Skerrett HE, Mulcahy G (2005) Possible mechanisms underlying age-related resistance to bovine babesiosis. Parasitol Immunol 27(4): 115-120.

5. Vairamuthu S, Pazhanivel N, Suresh RV, Balachandran (2012) Babesia bigemina in a 20 day old non-descript calf: a case. Indian J of Field Vet $7(4): 69$.

6. Venu R, Sailaja N, Srinivasa Rao K, Jayasree N, Vara Prasad WL (2015) Babesia bigemina infection in a 14-day old Jersey crossbred calf: a case report, J Parasit Dis 39(2):264 -265.

7. Yeruham I, Avidar Y, Aroch I, Hadani A (2003) Intra-uterine infection with Babesia bovis in a 2-day-old calf. J Vet Med B infect Dis vet public Health 50(2): 60-62.

8. Radostits OM, Gay CC, Hinchcliff KW, Constable PD (2007) Veterinary medicine. A text book of the diseases of cattle, sheep, pigs and horses, $\left(10^{\text {th }}\right.$ edn $)$, W B Saunders Co. Ltd., London

9. Sivajothi S, Reddy BS (2017) Management of dermatological lesions associated with Babesia gibsoni in dogs. Explor Anim Med Res 7(2): 213-215.

10. Sivajothi S, Reddy BS, Rayulu VC, Venkatasivakumar R (2014) Babesiosis in dogs: A report of two different cases. Advances in Applied Science Research 5(3): 276-279.
Creative Commons Attribution 4.0 International License

For possible submissions Click Here

\section{Submit Article}

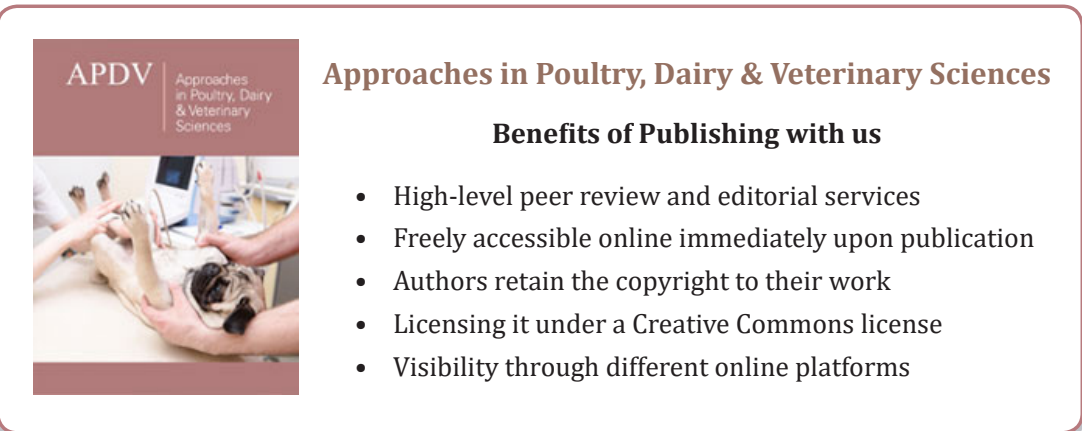

